Kansas State University Libraries

New Prairie Press

\title{
COMPARISON OF HOP DOWNY MILDEW EPIDEMICS USING SPATIAL ANALYSIS
}

\author{
J. Richard Alldredge \\ Dennis A. Johnson \\ Rochelle Allwine
}

Follow this and additional works at: https://newprairiepress.org/agstatconference

Part of the Agriculture Commons, and the Applied Statistics Commons

\section{(c) $(1) \Theta \Theta$}

This work is licensed under a Creative Commons Attribution-Noncommercial-No Derivative Works 4.0 License.

\section{Recommended Citation}

Alldredge, J. Richard; Johnson, Dennis A.; and Allwine, Rochelle (1989). "COMPARISON OF HOP DOWNY MILDEW EPIDEMICS USING SPATIAL ANALYSIS," Conference on Applied Statistics in Agriculture. https://doi.org/10.4148/2475-7772.1454

This is brought to you for free and open access by the Conferences at New Prairie Press. It has been accepted for inclusion in Conference on Applied Statistics in Agriculture by an authorized administrator of New Prairie Press. For more information, please contact cads@k-state.edu. 


\section{COMPARISON OF HOP DOWNY MILDEW EPIDEMICS} USING SPATIAL ANALYSIS

J. Richard Alldredge, Dennis A. Johnson, Rochelle Allwine

First and third authors: associate professor and technical assistant, respectively, Program in statistics, washington State University, Pullman 99164; second author: associate and extension plant pathologist, Washington State University Irrigated Agriculture and Extension Center, Prosser 99350.

\section{ABSTRACT}

Methods of spatial analysis including distribution fitting, variance-to-mean ratios, Morisita's index, doublet and runs analyses, Greig-smith analysis and variography were used to investigate the spatial pattern of hop downy mildew. Use of these methods allowed examination of the spatial structure of hop downy mildew at three spatial scales: within hop hills, between nearby hop hills, and for hop hills more separated in space. The results obtained were in general agreement for methods of analysis which assessed spatial structure at the same spatial scale with the exception of Morisita's index of clumping which did not identify clumps of diseased hills of the same size as Greig-smith analysis and semi-variograms.

Keywords: Spatial analysis, downy mildew, pattern, aggregation, dispersion.

\section{INTRODUCTION}

Epidemics of downy mildew of hop in Washington are usually of short duration because favorable weather in May is generally followed by unfavorable hot, dry conditions in June (11). Severe epidemics have occurred in the Yakima Valley an average of one in three years (11). The pathogen, Pseudoperonospora humuli (Miy. et Tak.) Wils., overwinters as mycelium in infected hop crowns (19). Plant shoots growing from infected crowns in the spring may become systemically infected and are known as primary spikes. sporangia from primary spikes are wind blown and cause infection of the apical meristem of healthy hop shoots, producing secondary spikes, when environmental conditions are favorable.

The spatial and temporal pattern of hop downy mildew is of interest to help understand and manage the disease. A knowledge of the pattern of downy mildew occurrence in hop yards would increase sampling efficiency for estimation of disease incidence $(3,16)$. In washington state hops are grown in a regular, square pattern of hills with a distance of approximately $3 \mathrm{~m}$ between hill centers. The data consist of hill location and disease incidence in the hill. The objective of this study was to use several spatial analysis 
methods to compare spatial pattern of disease from two years with quite different levels of disease incidence.

\section{MATERIALS AND METHODS}

Hop plants in the Yakima Valley of Washington were assessed visually in 1985 and 1988. In 1985 there was a mild epidemic while in 1988 a severe epidemic occurred because of favorable weather conditions. In 1985 six hop yards were chosen for study (10). In 1988 two of the same yards were observed along with two additional yards. The yards, which contained cultivars susceptible to downy mildew, were located throughout the hop growing area of washington state. Three of the yards in 1985 were near the town of Moxee (Moxee I, II, III), one near Sunnyside (Sunnyside I), and two near Mabton (Mabton I and II). In 1988, Sunnyside I and Mabton II were observed again and one yard near Wapato (Wapato) and another yard near Sunnyside (Sunnyside II) were chosen. Hills in a rectangular or square section of each yard were assessed one to five times at 10- to 25-day intervals to determine the number of primary and secondary spikes at each hill. Many main and lateral shoots arise from the perennial crown and all of these may become infected and produce spikes. Between 4800 and 9292 hills were observed in each yard on each sampling day. The study section of each yard was selected by choosing a hill randomly to begin observations that would include the desired length and width. In 1985 dimensions of the study sections in the yards ranged from $80 \times 80$ hills at Moxee I to $101 \times 92$ hills at Mabton I (10). In 1988 the dimensions of study sections were reduced for three of the four yards after the initial reading date due to time limitations. The dimensions were $92 \times 88$ for the first date at sunnyside I and $60 \times 88$ for the second reading, $48 \times 90$ for Mabton II for both observation dates, and $80 \times 80$ for the first reading at both Sunnyside II and Wapato and $60 \times 80$ for the later readings. some hills in each yard did not have live crowns so disease incidence counts were missing from these locations. These missing observations were treated as 0 disease for the analyses reported in this paper.

Distribution fitting, variance to mean ratios, Morisita's index (15), doublet and runs analyses $(4,7,8)$, Greig-smith analysis (9), Morisita's clumping index $(15,17)$, and semivariograms (13) were used to examine the spatial structure of downy mildew within hills, between nearby hills, and for hills more separated in space. Chi-square goodness-of-fit distribution fitting, variance-to-mean ratio, and Morisita's index allowed examination of disease variability within the hill. Greig-Smith and Morisita's index were used to search for clumps of diseased hills. A spatial auto-correlation method, the semi-variogram was employed to look for association among disease incidence counts in spatially contiguous hills. Runs and doublet analyses were used to search for small sized clumps of diseased hills. 
Disease incidence counts were combined into frequency categories, and adjacent categories that had small expected frequencies were pooled until the cumulative frequency exceeded one. A FORTRAN program developed by Gates and Ethridge (6) was used to calculate the chi-square goodness-offit statistic of the data to the Negative Binomial, Neyman Type A, Poisson, Poisson-Binomial, Poisson with Zeros, and Thomas Double Poisson Distributions (12).

Two indices of dispersion were used to indicate departures from randomness in spatial patterns. The ratio of the variance to the mean is expected to be less than one for a uniform spatial pattern, equal to one for a random spatial pattern, and greater than one for a spatially aggregated population (2l). The ratio generally increases as aggregation becomes more intense. Morisita's index of dispersion was also computed and compared to one in the same manner as the variance-to-mean ratio.

An index of clumping based on Morisita's index and a related method suggested by Greig-Smith were used to indicate the number of hills in disease incidence clumps $(9,15,17)$. counts were obtained for a series of successively doubled areas, in our case starting with one hill and ending with an area of 128 hills. An index of clumping (IC) was computed by dividing Morisita's index for an area of $x$ hills by Morisita's index for an area of $2 \mathrm{X}$ hills. The index of clumping was computed for the whole series of areas and plotted against area of $2 \mathrm{X}$. The area at which $I C$ is a maximum provides an estimate of the number of hills in a disease incidence clump. The Greig-smith procedure amounts to construction of a hierarchical analysis of variance in which the total variation is apportioned to the component variations at each area in the successively doubled areas. The peak will be maintained for larger areas provided the clumps are not regularly spaced. An approximate F-test was used to indicate evidence of existence of clumps (20).

Spatial autocorrelation was examined with semi-variance graphs, known as semi-variograms (13). These semi-variograms display the degree of correlation between disease counts from spatially contiguous hills at successively larger distances. The distance over which the semi-variogram continues to increase indicates the range of influence of diseased hills on nearby hills. Although not considered in this paper, the semi-variogram may also be used as input to the Kriging method which provides optimal, unbiased estimates of variables at unsampled locations (14).

Aggregation of diseased hills was also examined with doublet analysis $(4,8)$. Doublet analysis was used to compare the observed number of adjacent alseased plants, a doubiet, to the number expected if the disease were randomly distributed in the yard. If the observed number is greater than the expected number, contagion within the field is suspected. Doublet analysis was used to examine direction of spread in the direction of each axis of the rectangular hop yards, and in two diagonal directions. 
A runs analysis (7) was used to examine aggregation of diseased hills compared to mixing of diseased and healthy hills as expected for randomly distributed occurrence of disease. A run is defined as a succession of one or more diseased or healthy plants, which are followed and preceded by a plant of the other disease status or no plant at all. There would be few runs if there was an aggregation of diseased or healthy plants and a large number of runs for a random mixing of diseased and healthy plants. The ordinary runs analysis (7) was modified to allow combining adjacent rows for the analysis. Under the null hypothesis of randomness, the expected value of the total number of runs in the $i$ th row, say $U_{i}$, is given by:

$E\left(U_{i}\right)=1+2 m_{i}\left(N_{i}-m_{i}\right) / N_{i}$

where $m_{i}$ represents the number of infected plants in the $i$ th row which has $\mathrm{N}_{i}$ total plants. The standard deviation of $\mathrm{U}_{i}$ is given by:

$S\left(U_{i}\right)=\left(2 m_{i}\left(N_{i}-m_{i}\right)\left[2 m_{i}\left(N_{i}-m_{i}\right)-N_{i}\right] /\left[N_{i}^{2}\left(N_{i}-I\right)\right]\right)^{1 / 2}$

A test statistic with an asymptotic normal distribution may be defined as:

$\mathrm{Z}(\mathrm{U})=\left[\sum \mathrm{U}_{i}+0.5-\sum \mathrm{E}\left(\mathrm{U}_{i}\right)\right] / \sum \mathrm{S}\left(\mathrm{U}_{i}\right)$

The value of $Z(U)$ will be a large negative number if there is clustering so the test for nonrandomness is left-tailed. The runs test was applied in the row direction and the column direction of the rectangular hop yards.

\section{RESULTS}

Weather favored development of a mild epidemic in 1985 and a severe epidemic in 1988. Disease incidence was less than $2.0 \%$ throughout the observation period in all yards in 1985. During 1988 primary and secondary disease incidence increased from $1.6 \%$ to $68 \%$ at sunnyside $I$, from $15 \%$ to $60 \%$ at Mabton II, from $2.5 \%$ to $30 \%$ at Sunnyside II, and from $1.6 \%$ to $26 \%$ at Wapato.

In 1985, the goodness-of-fit statistic indicated that usually the Negative Binomial provided a better model than other distributions considered (Table 1). In contrast, the Negative Binomial was the best fitting distribution only for the initial sampling date in 1988. For later dates, none of the distributions considered provided an adequate fit to the incidence of primary and secondary disease (Table 1).

For both 1985 and 1988 the variance-to-mean ratio was significantly $(P<0.01)$ greater than one for incidence of primary disease on the first sampling date and combined incidence of primary and secondary disease on all other dates (1). Morisita's index was numerically larger than one for all locations and dates. 
Peaks in the value of IC and the Greig-smith sum of squares, as well as approximate F-tests (20), gave inconsistent results for clump size (Table 1). A reinterpretation of the 1985 data (10) indicated that Morisita's index of clumping identified several potential clumps of varying size for each location and date. Several potential clump sizes were also identified for the 1988 data by Morisita's index. The approximate F-tests for the GreigSmith index were non-significant for all locations and dates for the 1985 data. Clumps were identified by the Greig-Smith approximate F-tests for 1988 later sampling dates except at the Mabton II location (Table 1).

Semi-variogram graphs were generally horizontal in 1985 indicating no spatial autocorrelation among disease incidence in contiguous hills. An exception was semi-variograms for the primary and secondary data at sunnyside I for all dates combined where some spatial autocorrelation and periodic behavior was indicated. Semi-variogram graphs for 1988 indicated much more spatial autocorrelation than in 1985. Data from the last four dates for Wapato produce semivariograms which indicate autocorrelation between disease incidence in hills in all four directions examined with a range of influence of up to 8 hills. Semi-variograms for the last two dates for Sunnyside II showed some auto-correlation in the $Y$ direction with a range of influence of about 4 hills and the last date for sunnyside I showed some autocorrelation in the $X$ direction with a range of influence of about 8 hills. For the 1985 data, combined across dates because of low disease incidence, the doublet analysis indicated aggregation in most locations (Table 2). An approximate $z$-test (4) indicated that there was significant aggregation in all four directions for Sunnyside I and Mabton I and significant aggregation in three directions for Moxee III. The other yards had significant z-values for one or two directions. In 1988 the doublet analysis of data for the first date in all locations showed aggregation in fewer directions than the analysis on later dates. Significant z-tests were computed for all four directions for the later dates at all locations in 1988. The doublet analysis showed no evidence of an increase in disease spread in the direction of the prevailing wind in either year.

The modified runs test was applied to the $X$ and $Y$ directions for all the yards. The conclusion based on the runs analysis concerning aggregation was generally the same as that found using the doublet analysis (Table 2).

\section{DISCUSSION}

An aggregated rather than random or regular pattern was expected for hop downy mildew because new infections are more likely to occur near an inoculum source $(2,5,18)$. Dispersal of primary inoculum of $P$. humuli in hop yards was found to be short-range because primary spikes are close to the ground and often sheltered within a canopy of healthy basal shoots(16). 
We found aggregation of disease within the hill in both 1985 and 1988 as shown by variance-to-mean ratios and Morisita's index having values greater than one. In 1985 and the first sampling dates in 1988 when disease incidences were low, the Negative Binomial distribution provided a good representation of the frequency distribution of disease incidence. None of the distributions we examined fit the data for the later dates well in 1988. The 1985 distribution fitting results supported the conclusion of clumping within the hill but the 1988 data provided no evidence for deciding the type of pattern present.

The methods used to examine aggregation of diseased hills into clumps, namely Morisita's index of clumping, Greig-smith index, and semi-variograms gave inconsistent results. Aggregation of diseased hills into clumps of several different sizes was suggested by Morisita's index of clumping in both 1985 and 1988. The Greig-Smith analysis and the associated Ftest did not agree with the clump sizes suggested by

Morisita's index in either year. In 1985, no evidence of clumps of diseased hills was found by the Greig-Smith analysis nor was there evidence of clumping for the initial dates for any locations in 1988. However in 1988, the later dates in all locations, except Mabton II, showed evidence of disease clumping. The clump sizes were varied, consisting of from 2 to $32 \mathrm{hills}$. In 1985 semi-variograms showed little evidence of spatial autocorrelation. Semi-variograms for 1988 indicated spatial association among diseased hills with a range of influence no greater than 8 hills. This result supports the size of the clumps identified by Greig-smith (e.g., 32 hills $=4$ hill $x 8$ hill clump or 16 hills $=4$ hill $\mathrm{x}$ 4 hill clump). The agreement is not surprising because the semi-variance computed for a series of increasing lag distances is related to the nested variance computed from clumps of increasing numbers of hills.

Both the doublet and the runs analyses indicated aggregation of disease occurrence, where occurrence is defined as presence or absence of disease in the hill. In 1985 significant aggregation occurred in at least one direction in each yard for data combined across dates. Some yards had significant doublet and runs test statistics in all directions precluding any conclusions about increased spread in the direction of prevailing winds. In 1988, significant doublets and runs occurred in all directions in all yards on the later dates and for all dates combined. Aggregation in the direction of prevailing winds was not observed, perhaps because wind direction during rainfall, which would support disease spread, is quite variable (10).

In summary, there appeared to be aggregation of disease incidence within the hills for all yards on all dates for both years. Evidence of aggregation between nearby hills was most consistent for later dates in 1988 when more disease was present. Spatial association between contiguous hills as well as more widely separated hilis was not direction dependent. The time since the hop yard was established may have affected 
the pattern of downy mildew occurrence. In 1985, hop plants in yards Moxee III, Sunnyside I, and Mabton I had been planted for five, six and 20 years, respectively. The other three yards had been in production for 25, 30, and 40 years. The three youngest yards had significant aggregation of adjacent diseased hills in at least three directions. In 1988, all four yards had significant aggregation of adjacent diseased hills in all directions for later dates of sampling. However in 1988 the oldest yard, Mabton II (28 years), did not exhibit aggregation of larger clumps or spatial autocorrelation over larger distances in contrast with the three youngest yards, Sunnyside I ( 9 years), Sunnyside II ( 6 years), and wapato (8 years). Depending on winter weather, the older yards would have had more infected crowns die and be replaced than the younger yards, and a more aggregated pattern could have been changed to a less aggregated pattern over time.

The statistical methods used were in general agreement and provided information about spatial structure at several spatial scales. Morisita's index and the variance to mean ratio identified aggregation of disease incidence within hills even though probability distributions associated with clumped data often did not fit the data well. Doublet and runs analyses were usually consistent in identifying aggregation of disease occurrence among contiguous hills. The index of clumping based on Morisita's index did not effectively identify disease incidence clumps. The Greig-Smith method and semi-variograms were generally consistent in identifying disease incidence clumps for the later dates in 1988 which is also consistent with the increased aggregation of disease occurrence identified by the runs and doublet analyses.

\section{IITERATURE CITED}

1. Bartko, J.J., Greenhouse, S.W., and Patlak, C.S. 1968. On expectations of some functions of Poisson variates. Biometrics 24:97-102.

2. Boivin, G., and Sauriol,P. 1984. Dispersion statistics and sequential sampling plan for leaf blight caused by Botrytis squamosa in onions. Phytopathology 74:1385-1387.

3. Campbell, C.I., and Noe, J.P. 1985. The spatial analysis of soilborne pathogens and root diseases. Annu. Rev. Phytopathol. $23: 129-148$.

4. Converse, R.H., Seely, J., and Martin, L.W. 1979. Evidence of random local spread of aphid-borne mild yellow-edge virus in strawberries. Phytopathology 69:142-144.

5. Danos, E., Berger, R.D., and Stall, R.E. 1984. Temporal and spatial spread of citrus canker within groves. Phytopathology $74: 904-908$. 
6. Gates, C.E. and Ethridge, F.G. 1972 A generalized set of discrete frequency distributions with FORTRAN program. Math Geol. 4:1-24.

7. Gibbons, J.D. 1976. Nonparametric Methods for Quantitative Analysis. Holt, Reinhart and Winston, New York. 463pp.

8. Gitaitis, R.D., Stall, R.E., and Strandberg, J.0. 1978. Dissemination and survival of Pseudomonas alboprecipitans ascertained by disease distribution. Phytopathology 68:227231.

9. Greig-Smith, P. 1952. The use of random and contiguous quadrats in the study of the structure of plant communities. Ann. Bot. 16:293-316.

10. Johnson, D.A., Alldredge, J.R., and Fisher, R. 1988. Spatial pattern of downy mildew in hop yards. Phytopathology 78:1389-1395.

11. Johnson, D.A., Skotland, C.B., and Alldredge, J.R. 1983. weather factors affecting downy mildew epidemics of hops in the Yakima Valley of Washington. Phytopathology 73:490-493.

12. Johnson, N.L., and Kotz, S. 1969. Discrete Distributions. John Wiley and Sons, New York. 328pp.

13. Journel, A.G., and Huijbregts, Ch.J. 1978. Mining Geostatistics. Academic Press, New York. 600pp.

14. Lecoustre, R., Fargette, D., Fauquet, C., and de Reffe, P. 1989. Analysis and mapping of the spatial spread of African cassava mosaic virus using geostatistics and the Kriging technique. Phytopathology 79:913-920.

15. Morisita, M. 1959. Measuring and the dispersion and analysis of distribution patterns. Mem. Fac. Sci. Kyushu Univ. Ser. E 62:215-235.

16. Nicot, P.C., Rouse, D.I., and Yandell, B.S. 1984. Comparison of statistical methods for studying spatial patterns of soilborne plant pathogens in the field. Phytopathology 74:1399-1402.

17. Schuh, W., Frederiksen, R.A., and Jeger, M.J. 1986. Analysis of spatial patterns with Morisita's index of dispersion in sorghum downy mildew. Phytopathology 76:446-450.

18. Scott, G.E. 1985. Nonrandom spatial distribution of aphidvectored maize dwarf mosaic. Plant Dis. 69:893-895. 
19. Skotland, C.F. 1961. Infection of hop crowns and roots by Pseudoperonospora humuli and its relation to crown and root rot and overwintering of the pathogen. Phytopathology 51:241244.

20. Thompson, H.R. 1958.. The statistical study of plant distribution patterns using a grid of quadrats. Aust. J. Bot. $6: 322-342$.

21. Upton, G., and Fingleton, B. 1985. Spatial Data Analysis by Example. Vol 1. John Wiley and Sons, New York. 410pp. 
TABIE 1. Summary of indices for incidence of primary and secondary infections of pseudoporonospora humuli in hop plants in one mild and one severe epidemic year.

\begin{tabular}{|c|c|c|c|c|c|c|c|}
\hline Location & Date & $\begin{array}{l}\text { Best-ritting } \\
\text { distribution }\end{array}$ & $\begin{array}{l}\text { Probb } \\
\text { value }\end{array}$ & Morisita's & Var/mean & $\begin{array}{l}\text { Index of } \\
\text { clumping }\end{array}$ & $\begin{array}{c}\text { Greig-smith C } \\
\text { peak }\end{array}$ \\
\hline Sunnyside I & $\begin{array}{l}5 / 15 / 85^{*} \\
5 / 28 \\
6 / 10 \\
5 / 21\end{array}$ & $\begin{array}{l}\text { NTA } \\
\text { NB } \\
\text { NB } \\
\text { NB }\end{array}$ & $\begin{array}{l}0.577 \\
0.725 \\
0.528 \\
0.104\end{array}$ & $\begin{array}{l}186.70 \\
265.91 \\
255.66 \\
152.50\end{array}$ & $\begin{array}{l}2.22 \\
2.42 \\
2.50 \\
5.31\end{array}$ & $\begin{array}{l}2 \mathrm{H}, 16 \mathrm{H}, 4 \mathrm{~V}, 32 \mathrm{~V}, 128 \mathrm{~B} \\
2 \mathrm{H}, 8 \mathrm{H}, 16 \mathrm{H}, 4 \mathrm{~V}, 64 \mathrm{~V} \\
2 \mathrm{~B}, 64 \mathrm{H} \\
16 \mathrm{H}, 64 \mathrm{H}, 8 \mathrm{~V}\end{array}$ & $\overline{-}$ \\
\hline Mabton II & $\begin{array}{l}5 / 14 / 85^{*} \\
5 / 24\end{array}$ & $\begin{array}{l}\text { NTA } \\
\text { NB }\end{array}$ & $\begin{array}{l}0.553 \\
0.006\end{array}$ & $\begin{array}{l}227.69 \\
285.67\end{array}$ & $\begin{array}{l}2.69 \\
4.39\end{array}$ & $\begin{array}{l}2 \mathrm{~B}, 128 \mathrm{H} \\
2 \mathrm{~B}, 16 \mathrm{H}, 128 \mathrm{H}, 64 \mathrm{~V}\end{array}$ & - \\
\hline Moxee III & $5 / 10 / 85^{\star}$ & KB & 0.589 & 260.85 & 2.61 & $2 \mathrm{H}, 64 \mathrm{H}, 4 \mathrm{~V}, 32 \mathrm{~V}$ & -- \\
\hline Moxee II & $\begin{array}{l}5 / 13 / 85^{\circ} \\
5 / 31 \\
6 / 19\end{array}$ & $\begin{array}{l}\text { NB } \\
\text { NB } \\
\text { PB }\end{array}$ & $\begin{array}{l}0.827 \\
0.113 \\
0.469\end{array}$ & $\begin{array}{l}80.11 \\
82.03 \\
57.65\end{array}$ & $\begin{array}{l}2.04 \\
2.72 \\
1.54\end{array}$ & $\begin{array}{l}2 \mathrm{~B}, 8 \mathrm{H}, 128 \mathrm{~V} \\
2 \mathrm{~B}, 64 \mathrm{H} \\
8 \mathrm{~B}, 32 \mathrm{H}, 2 \mathrm{~V}, 64 \mathrm{~V}\end{array}$ & $=$ \\
\hline Mabton I & $\begin{array}{l}5 / 07 / 85^{\star} \\
5 / 22 \\
6 / 05\end{array}$ & $\begin{array}{l}\text { NB } \\
\text { NB } \\
\text { NB }\end{array}$ & $\begin{array}{l}0.356 \\
0.003 \\
0.551\end{array}$ & $\begin{array}{l}328.44 \\
395.49 \\
599.74\end{array}$ & $\begin{array}{l}4.42 \\
5.15 \\
3.78\end{array}$ & $\begin{array}{l}2 \mathrm{~B}, 64 \mathrm{~V} \\
2 \mathrm{H}, 8 \mathrm{H},, 4 \mathrm{~V}, 16 \mathrm{~V}, 128 \mathrm{~B} \\
2 \mathrm{~B}, 64 \mathrm{H}\end{array}$ & $=$ \\
\hline Moxee I & $\begin{array}{l}5 / 09 / 85^{7} \\
5 / 23 \\
6 / 17\end{array}$ & $\begin{array}{l}\text { NB } \\
\text { NB } \\
\text { NB }\end{array}$ & $\begin{array}{l}1.000 \\
0.004 \\
0.806\end{array}$ & $\begin{array}{r}76.94 \\
81.62 \\
127.02\end{array}$ & $\begin{array}{l}2.84 \\
4.35 \\
3.02\end{array}$ & $\begin{array}{l}4 \mathrm{H}, 2 \mathrm{~V} \\
4 \mathrm{H}, 2 \mathrm{~V} \\
2 \mathrm{H}, 8 \mathrm{~V}\end{array}$ & $=$ \\
\hline Sunnyside I & $\begin{array}{l}5 / 03 / 88^{*} \\
5 / 03 \\
5 / 12\end{array}$ & $\begin{array}{l}\text { NB } \\
\text { NB } \\
--\end{array}$ & $\begin{array}{c}0.985 \\
0.030 \\
--\end{array}$ & $\begin{array}{r}55.55 \\
80.78 \\
3.12\end{array}$ & $\begin{array}{l}2.42 \\
4.07 \\
4.66\end{array}$ & $\begin{array}{l}2 \mathrm{~B} \\
2 \mathrm{~B}, 8 \mathrm{~V} \\
2 \mathrm{~B}, 8 \mathrm{~V}, 32 \mathrm{~V}, 22 \mathrm{VV}\end{array}$ & $4 B, 16 \mathrm{~V}$ \\
\hline Mabton II & $\begin{array}{l}5 / 06 / 88^{\prime} \\
5 / 06 \\
5 / 23\end{array}$ & $\begin{array}{l}\text { NB } \\
--\end{array}$ & $\begin{array}{c}0.034 \\
-- \\
--\end{array}$ & $\begin{array}{l}8.50 \\
6.92 \\
4.27\end{array}$ & $\begin{array}{l}4.08 \\
6.95 \\
6.77\end{array}$ & $\begin{array}{l}2 B \\
2 B \\
2 B\end{array}$ & $\overline{--}$ \\
\hline Sunnyside II & $\begin{array}{l}4 / 28 / 88^{*} \\
4 / 28 \\
5 / 12 \\
5 / 26\end{array}$ & $\begin{array}{l}\text { NB } \\
\text { NB } \\
-- \\
--\end{array}$ & $\begin{array}{c}0.151 \\
0.489 \\
\ldots \\
--\end{array}$ & $\begin{array}{l}50.12 \\
51.27 \\
13.76 \\
11.02\end{array}$ & $\begin{array}{l}3.25 \\
3.56 \\
7.27 \\
6.26\end{array}$ & $\begin{array}{l}2 \mathrm{H}, 8 \mathrm{H}, 32 \mathrm{H}, 128 \mathrm{H}, 4 \mathrm{~V} \\
2 \mathrm{H}, 8 \mathrm{H}, 32 \mathrm{H}, 128 \mathrm{H}, 4 \mathrm{~V} \\
2 \mathrm{~B}, 8 \mathrm{H}, 32 \mathrm{H}, 16 \mathrm{~V} \\
2 \mathrm{~B}, 8 \mathrm{H}, 32 \mathrm{H}, 2 \mathrm{~V}, 16 \mathrm{~V}\end{array}$ & $\begin{array}{c}-- \\
16 \mathrm{H}, 32 \mathrm{~V} \\
26 \mathrm{H}, 32 \mathrm{~V}\end{array}$ \\
\hline Wapato & $\begin{array}{l}4 / 29 / 88^{\prime} \\
4 / 29 \\
5 / 13 \\
5 / 31 \\
6 / 15 \\
6 / 28\end{array}$ & $\begin{array}{l}\text { NB } \\
\text { KB } \\
-- \\
-- \\
--\end{array}$ & $\begin{array}{c}0.260 \\
0.234 \\
=- \\
=- \\
=-\end{array}$ & $\begin{array}{r}62.71 \\
62.74 \\
21.10 \\
17.36 \\
8.59 \\
4.09\end{array}$ & $\begin{array}{l}2.71 \\
2.81 \\
2.22 \\
7.54 \\
3.28 \\
2.13\end{array}$ & $\begin{array}{l}2 \mathrm{H}, 16 \mathrm{H}, 64 \mathrm{H}, 8 \mathrm{~V}, 32 \mathrm{~V} \\
2 \mathrm{H}, 16 \mathrm{H}, 64 \mathrm{H} \\
2 \mathrm{~B}, 8 \mathrm{~B}, 12 \mathrm{~B} \\
8 \mathrm{~B}, 128 \mathrm{H}, 2 \mathrm{~V} \\
2 \mathrm{~B}, 128 \mathrm{~B} \\
2 \mathrm{~B}, 128 \mathrm{~B}\end{array}$ & $\begin{array}{l}-- \\
2 \mathrm{H}, 4 \mathrm{~V}, 32 \mathrm{~V} \\
2 \mathrm{H}, 4 \mathrm{~V} \\
16 \mathrm{~B} \\
16 \mathrm{H}, 8 \mathrm{~V}\end{array}$ \\
\hline
\end{tabular}

* primary spike data only

a Distribution that best fits the data according to the chisquare goodness-of-fit test. NTA = Neyman Type A; NB = Negative Binomial; $\mathrm{PB}=$ Positive Binomial; -- = None.

b probability value for the chi-square goodness-of-fit test.

c Number of hills in a disease incidence clump consisting of $4,8,16$, etc. hills. $\mathrm{H}=$ horizontal orientation for rectangular blocks of contiguous hilis; $V=$ vertical orientation used for rectangular blocks of contiguous hills; $B=$ both horizontal and vertical clumps; and - $=$ no indication of clumps of diseased plants for block sizes examined.

NewPrairiePress

https//nemprairiepressorg/agtctconference 1989/proceeding//9 
TABIE 2. Doublet and runs analyses of bop plants with primary and secondary infection of Pseucoperonospora bumuis in bop yards for one mild and one severe epicemic yeaz.

\begin{tabular}{|c|c|c|c|c|c|}
\hline \multirow[b]{2}{*}{ Lecetion } & \multirow[b]{2}{*}{ Dete } & \multicolumn{3}{|c|}{ Direction b } & \multirow[b]{2}{*}{ Diac2 } \\
\hline & & \pm & $x$ & Qjec2 & \\
\hline Sunnyside I & $1985^{a}$ & 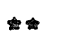 & 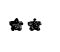 & 电 & 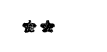 \\
\hline Mabton II & 2985 & 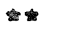 & Is & ns & ns \\
\hline Moxee III & 1985 & $\Leftrightarrow$ & $*-$ & 宙 & ns \\
\hline Moxee II & 9985 & ns & का & นิs & 实电 \\
\hline Mabton I & 2985 & 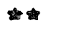 & - & 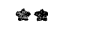 & 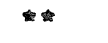 \\
\hline Moxee I & 2985 & $-\frac{1}{\#}$ & $\pi s$ & 윞 & rs \\
\hline sunnyside I & $\begin{array}{l}5 / 03 / 88^{1} \\
5 / 03 \\
5 / 12 \\
2988\end{array}$ & 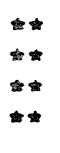 & $\begin{array}{l}\text { ns } \\
\text { ns } \\
\text { s. }\end{array}$ & $\begin{array}{l}\text { ns } \\
\text { ns } \\
\text { tin }\end{array}$ & $\begin{array}{l}\text { ns } \\
\text { ns } \\
\text { t }\end{array}$ \\
\hline Mabton II & $\begin{array}{l}5 / 06 / 88^{*} \\
5 / 06 \\
5 / 23 \\
1988\end{array}$ & 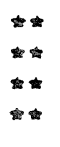 & $\begin{array}{l}\neq \\
\Rightarrow \\
\neq\end{array}$ & 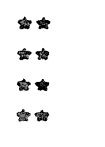 & $\begin{array}{l}\text { ns } \\
+\infty \\
m\end{array}$ \\
\hline Sunnyside II & $\begin{array}{l}4 / 28 / 88 \\
4 / 28 \\
5 / 22 \\
5 / 26 \\
1988\end{array}$ & $\begin{array}{l}- \\
\Rightarrow \\
= \\
*\end{array}$ & $\begin{array}{l}\text { ns } \\
\text { ns } \\
t= \\
0\end{array}$ & $\begin{array}{l}\text { ns } \\
\text { ns } \\
= \\
m\end{array}$ & 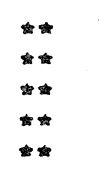 \\
\hline Wapato & $\begin{array}{l}4 / 29 / 88^{\circ} \\
4 / 29 \\
5 / 23 \\
5 / 31 \\
6 / 15 \\
6 / 28 \\
1988\end{array}$ & $\begin{array}{l}\text { ns } \\
\text { ns } \\
1 \\
1 \\
* \\
1\end{array}$ & $\begin{array}{l}\text { ns } \\
n s \\
m \\
m \\
m \\
\# \\
\#\end{array}$ & 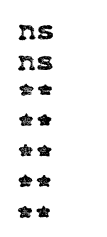 & 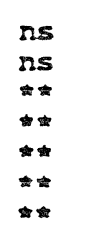 \\
\hline
\end{tabular}

a 1985, 1988 a data for all dates combined; - primazy data only

b significance of doublet and funs analyses:

* - Significant aggregation (P=0.05) according to

approximate $z$-tests foz both the doublet and runs analysis. ns = Nonsignilicant aggregation ( $P>0.05$ ) according to approximate $z$-tests for both the doublet and funs analyses. - a Significant aggregation according to doublet anaiysis but nonsignificant according to rurs analysis. - Significant aggregation according to zun analysis but ronsignificant according to doublet analysis. 